\title{
Edge effects and succession dynamics in Brachidontes mussel beds
}

\author{
Marcel O. Tanaka ${ }^{1, *}$, Cláudia A. Magalhães ${ }^{2}$ \\ ${ }^{1}$ Programa de Pós-Graduação em Ecologia and ${ }^{2}$ Departamento de Zoologia, Instituto de Biologia, \\ Universidade Estadual de Campinas, CP 6109, Campinas, SP, 13083-970, Brazil
}

\begin{abstract}
Succession dynamics in natural communities can be influenced both by interactions among recruiting species and by characteristics of the gaps created by disturbances such as the perimeter:area (P:A) ratio. We carried out experiments on 2 subtropical shores in SE Brazil to investigate the influence of gap size (P:A ratio and area variable) and shape (P:A ratio constant and area variable) on the succession of mussel beds dominated by Brachidontes solisianus and B. darwinianus. Small gaps harbored more herbivorous gastropods (mainly the limpet Collisella subrugosa) and were more rapidly preempted by lateral migration of the surrounding mussels than larger gaps. The larger gaps had higher densities of the barnacle Chthamalus bisinuatus and sheltered more limpets in the edges, while the core areas had more Brachidontes recruits. Gaps with different areas but constant $\mathrm{P}: \mathrm{A}$ ratios had similar succession trends. Although the processes that influence gap closure in other mussel bed species are similar to the studied one, the closure rate in Brachidontes was lower, possibly due to bed structure. However, there were differences between both mussel species, with a faster response to gap formation by $B$. darwinianus in comparison to $B$. solisianus, suggesting that disturbances can influence the distribution of these species. The relative influence of edge effects on succession processes may differ among communities dominated by different organisms, and generalizations are possibly restricted to communities composed of functionally similar species.
\end{abstract}

KEY WORDS: Succession $\cdot$ Mussel beds $\cdot$ Brachidontes $\cdot$ Gap size $\cdot$ Intertidal communities Resale or republication not permitted without written consent of the publisher

\section{INTRODUCTION}

Within established intertidal communities, denuded gaps are often formed after environmental disturbances, offering substrate for new settlement of species (Levin \& Paine 1974, Connell \& Keough 1985, Sousa 1985). After different phases of succession, gap dynamics may stabilize and display similar characteristics to the ambient community (Connell \& Slatyer 1977). Gaps opened within sessile intertidal communities in emergent substrata can be colonized both by larvae and propagules coming from the water column, and by lateral migration of the neighboring species,

\footnotetext{
${ }^{*}$ Present address: Departamento de Biologia, Setor Ecologia, CCBS, CP 549, Universidade Federal de Mato Grosso do Sul, Campo Grande, MS, 79070-900, Brazil.

E-mail:martnk@yahoo.com
}

including vegetative growth by macroalgae and colonial species (Dayton 1971, Dean \& Hurd 1980, Keough 1984, Sousa 1984a, 1985, Farrell 1989).

Disturbance intensity, defined by the size of the formed gap, can influence succession patterns. As a consequence of the greater area, larger patches should sample more species from the available pool, and have greater species richness than the small patches (Keough 1984, Sousa 1984b). Also, within the larger patches the physical conditions may differ between central and peripheral regions, restricting colonization or survival to only a few of the available species, and hence influencing succession dynamics (Sousa 1985). For mobile consumers, the milder conditions found in gap periphery can provide a refuge against environmental stresses such as temperature, desiccation and wave impact; thus, patches with a greater perimeter: area ratio should shelter greater densities of these ani- 
mals (Dayton 1971, Sousa 1984a, Farrell 1989, but see Underwood et al. 1983).

The composition of the surrounding community can also influence the colonization patterns of some species. The larger influence of sessile adults along the perimeter on small patches can facilitate the recruitment of conspecifics or competitors (Navarrette \& Castilla 1990, Minchinton 1997), influencing community structure. Another consequence of the larger perimeter relative to the area is the greater influence of the surrounding community through lateral migration (Paine \& Levin 1981, Keough 1984, Sousa 1984a). In this case, patches with different areas but similar edge relationships should have similar closure rates due to lateral invasion processes (Paine \& Levin 1981), but this prediction has as yet not been tested. Edge effects were tested in patches with the same shape but differing areas: small gaps are rapidly closed by invasion of the surrounding species, while large gaps close as propagules colonize from the water column (Paine \& Levin 1981, Sousa 1984b, Farrell 1989). However, this pattern is not always maintained, as interactions within a specific system can result in distinct species colonization rates, sometimes impairing generalizations (Kim \& DeWreede 1996).

The objective of this study was to analyze whether patches with different edge relationships influence the succession patterns of mixed Brachidontes mussel beds in 2 subtropical shores from SE Brazil. Brachidontes solisianus (d'Orbigny) and B. darwinianus (d'Orbigny) are important components of intertidal communities along the Brazilian coast, forming belts dominating the midlittoral zone (Klappenbach 1965, Eston et al. 1986, Petersen et al. 1986). Studies on the dynamics of mussel beds are generally dominated by work on Mytilus from temperate systems, which are larger species than Brachidontes and may form multiple layers on the rocky substrate (Seed \& Suchanek 1992). Brachidontes solisianus and $B$. darwinianus generally form a single layer, occurring in mixed beds or vertically separated (Nalesso et al. 1990). Thus, the relative influence of different mechanisms of gap closure (e.g. Paine \& Levin 1981) can differ between these systems as can the role of disturbances on community structure. Therefore, we specifically asked: (1) Do patches with the same shape but distinct areas and perimeter:area ratios have different colonization patterns? (2) Do patches with the same edge relationship but differing areas (i.e. shapes) have similar dynamics of succession?

\section{MATERIALS AND METHODS}

Study areas. This work was carried out at 2 nearby shores in the Ubatuba district, northern coast of São
Paulo State, SE Brazil. Both shores are moderately exposed to wave action and zonation patterns are representative of other semi-exposed shores in SE Brazil (Johnscher-Fornasaro et al. 1990). Praia da Barra $\left(23^{\circ} 29^{\prime} 50^{\prime \prime} \mathrm{S}, 45^{\circ} 09^{\prime} 90^{\prime \prime} \mathrm{W}\right)$ is located in the Rio Escuro estuary, where large granitic boulders shelter communities dominated by the barnacle Chthamalus bisinuatus Pilsbry in the upper midlittoral, the mussels Brachidontes solisianus and $B$. darwinianus in the intermediate region, and a lower belt dominated by several species of macroalgae and the oyster Crassostrea rhizophorae (Guilding). Lázaro $\left(23^{\circ} 31^{\prime} 50^{\prime \prime} \mathrm{S}, 45^{\circ} 08^{\prime} 20^{\prime \prime} \mathrm{W}\right.$ ) has a continuous granitic coast without any influence of freshwater, except for small water channels from the forest above the coast. Zonation patterns are similar to Barra, except for the bivalve Isognomon alatus Gmelin, which also occurred within the Brachidontes zone. More details of these areas can be found in Eston \& Bussab (1990) and Johnscher-Fornasaro et al. (1990).

Experimental designs. We carried out 2 experiments to evaluate succession patterns in patches with different edge relationships. Both experiments were arranged in randomised block designs in order to reduce the influence of spatial variation (Winer 1971). Gaps were scraped on the mussel beds in July 1994 using a putty knife and their edges marked with epoxy putty. A $10 \times 10 \mathrm{~cm}$ 'control' quadrat was also marked in each block, and was randomly allocated as a treatment level. The experiments lasted $18 \mathrm{mo}$ and treatments were sampled in 1 to 3 mo intervals.

To investigate the effect of patch size on succession dynamics, we made quadrats of 5,10 and $20 \mathrm{~cm}$ sides arranged in 7 blocks at Praia da Barra (Table 1). Recolonization was followed using $10 \times 10$ or $20 \times 20 \mathrm{~cm}$ quadrats with 81 points uniformly distributed. In the $5 \times 5 \mathrm{~cm}$ patches, we used a quadrat with 16 uniformly distributed points. All mobile species were counted and, during Chthamalus recruitment, we randomly subsampled ten $1 \mathrm{~cm}^{2}$ units and counted all barnacles therein.

Table 1. Measures of area, perimeter and perimeter:area ratio for the treatments used in each experiment

\begin{tabular}{|lccc|}
\hline Shape & $\begin{array}{c}\text { Area } \\
\left(\mathrm{cm}^{2}\right)\end{array}$ & $\begin{array}{c}\text { Perimeter } \\
(\mathrm{cm})\end{array}$ & $\begin{array}{c}\text { Perimeter: } \\
\text { area ratio }\end{array}$ \\
\hline Patch size effects & & & \\
$\quad$ Square & 25 & 20 & 0.8 \\
$\quad$ Square & 100 & 40 & 0.4 \\
$\quad$ Square & 400 & 80 & 0.2 \\
Patch shape effects & & & \\
$\quad$ Square & 100.0 & 40.0 & 0.4 \\
Circle & 78.5 & 31.4 & 0.4 \\
Rectangle & 112.5 & 45.0 & 0.4 \\
Sector & 190.1 & 78.6 & 0.4 \\
\hline
\end{tabular}


To compare the position within gaps, we subdivided the $20 \times 20 \mathrm{~cm}$ quadrat into 2 areas: (1) the edge, consisting of a strip with $5 \mathrm{~cm}$ width along the whole perimeter of the patch; and (2) the center, which is the remaining $10 \times 10 \mathrm{~cm}$ area within the patch, as defined by Farrell (1989). In both areas, organisms were counted and \% cover estimated.

Differences in patch shape were evaluated in an experiment set up in Lázaro using 6 blocks. The perimeter:area ratio was kept constant and the following shapes were used: quadrats, circles, rectangles and pairs of sectors with $90^{\circ}$ aligned one in front of the other (see Table 1 for dimensions). Patch areas varied from 78.5 to $190.1 \mathrm{~cm}^{2}$. All patches were sampled for the abundance of mobile species and \% cover estimated using quadrats with the patch shapes drawn on them, containing uniformly distributed points distant $1 \mathrm{~cm}$ from each other. For both experiments, controls were sampled using $10 \times 10 \mathrm{~cm}$ quadrats with 81 uniformly distributed points.

Previous observations indicated that patch areas used in the experiments were within the range of natural gaps that occurred in the intertidal assemblage. To test this assumption, we evaluated mean patch area at both sites in August 1996 (winter) and November 1996 (late spring). At each site, 3 horizontal transects ranging between 3 and $5 \mathrm{~m}$ in length were established in the Brachidontes zone; within each transect, we measured all natural gaps present.

Data analysis. We analyzed the experiments with repeated measures ANOVA (RM-ANOVA), using the Greenhouse-Geiser procedure to correct the F-value, since the condition of sphericity was never observed (correlations between sample pairs were not similar; Winer 1971). The univariate model used was:

$$
Y_{\mathrm{ijk}}=\mu+B_{\mathrm{i}}+T_{\mathrm{j}}+B T_{\mathrm{ij}}+A_{\mathrm{k}}+A T_{\mathrm{jk}}+A B_{\mathrm{ik}}+\text { error }
$$

where $B_{\mathrm{i}}$ is the effect of blocks, $T_{\mathrm{j}}$ the treatment effect and $A_{\mathrm{k}}$ is the time effect. The interaction $B T_{\mathrm{ij}}$ was used to test the effect of treatments and the error was used to test the effects of time and interactions. We also performed multivariate analyses on the repeated measures, as they are less subject to these correlations (Winer 1971). To achieve variance homogeneity, we converted densities to $\log (y+1)$ and \% cover to $\operatorname{asin} \sqrt{y+0.5}$. Residuals were graphically analyzed for normality and variance trends.

As each experiment was carried out on a different shore, the conclusions could be confounded by local effects (Hurlbert 1984). Thus, we compared the succession on the intermediate size quadrat between both shores. Migration rates and total \% cover did not differ (see 'Results'), so we assumed that succession dynamics at both sites was similar.

\section{RESULTS}

The studied sites had natural gaps with similar areas in August and November (2-way fixed ANOVA; Site: $F_{1,8}=0.9, \mathrm{p}=0.36$; Time: $F_{1,8}=2.0, \mathrm{p}=0.19$; Interaction: $\left.F_{1,8}=0.8, \mathrm{p}=0.40\right)$. Mean gap size at Barra was $69.7 \mathrm{~cm}^{2}( \pm 16.1 \mathrm{SE})$ and at Lázaro $88.8 \mathrm{~cm}^{2}$ $( \pm 17.7 \mathrm{SE})$. Total area of bare rock represented $6.7 \%$ $( \pm 1.1 \mathrm{SE})$ of the whole mussel bed area, with no differences between sites or sampling months (2-way fixed ANOVA; Site: $F_{1,8}=0.05, \mathrm{p}>0.80$; Time: $F_{1,8}=1.60$, $\mathrm{p}=0.24$; Interaction: $\left.F_{1,8}=0.08, \mathrm{p}>075\right)$. Size distributions did not differ between both sites (KolmogorovSmirnov test, $\mathrm{p}=0.80$ ), with prevalence of small gaps (0 to $50 \mathrm{~cm}^{2}, 56 \%$ of all gaps; 50 to $100 \mathrm{~cm}^{2}, 26 \% ; 100$ to $400 \mathrm{~cm}^{2}, 14 \% ;>400 \mathrm{~cm}^{2}, 3 \% ; \mathrm{n}=499$ ). Thus, gap sizes used in the experiments were within the range observed for natural gaps.

At Praia da Barra, Brachidontes solisianus initially dominated the substrate in control quadrats covering about $60 \%$ of the substrate and decreasing to $20 \%$ by the end of the study, while $B$. darwinianus increased from 35 to $80 \%$. Cover of Chthamalus on mussels was variable ( 0 to $20 \%$ ) and gradually dropped to 0 as barnacles died throughout the study. Herbivores also occurred in very low densities when present on mussels and were never observed before May 1995. Maximum densities recorded were 4.3 ind. $100 \mathrm{~cm}^{-2}$ for the acmaeid Collisella subrugosa and 23.7 ind. $100 \mathrm{~cm}^{-2}$ for the littorinid Nodilittorina lineolata by the end of the study.

The mussel Brachidontes solisianus also dominated the assemblage in control quadrats at Lázaro, covering about $45 \%$ of the substrate, while $B$. darwinianus varied around $25 \%$. The bivalve Isognomon alatus gradually increased in cover during the study, from near 0 values to $30 \%$ of the substrate. Chthamalus occurred on Brachidontes shells, but was only observed until December 1994, when all barnacles died; the initial mean value was $1.6 \%$. Herbivore gastropods occurred in low densities and included Nodilittorina lineolata (2.4 ind. $100 \mathrm{~cm}^{-2}$ ), Collisella subrugosa (1.7 ind. $\left.100 \mathrm{~cm}^{-2}\right)$ and Fissurella clenchi $\left(0.1\right.$ ind. $\left.100 \mathrm{~cm}^{-2}\right)$.

Recovery of patches in intermediate-sized quadrats was similar in Lázaro and Barra. There were no differences between shores of cover of lateral migrating species $\left(F_{1,5}=0.79, \mathrm{p}>0.80\right)$ and total cover of sessile species $\left(F_{1,5}=0.56, \mathrm{p}>0.45\right)$. Densities of the main herbivore, the gastropod Collisella subrugosa, were also similar, with very low values (see 'Gap area effects'). Colonization by the barnacle Chthamalus bisinuatus was out of phase, with higher densities at Barra (see 'Gap area effects'); however, recruitment occurred in peaks and individuals did not survive more than 2 mo within each shore. 


\section{Gap size effects}

Succession dynamics differed among small-, intermediate- and large-sized gaps at Barra. We detected recruitment of the barnacle Chthamalus bisinuatus in October 1994, reaching peak densities during early autumn in March 1995 (Fig. 1). Barnacle densities during this peak differed among treatment gaps (1-way ANOVA: $\left.F_{2,12}=8.74, \mathrm{p}<0.01\right)$. Densities in small- and intermediate-sized gaps were similar and both had lower densities than the large ones (Tukey's HSD multiple comparisons test, $\mathrm{p}<0.05)$. Barnacles died both on experimental gaps and within the natural population, dropping to values near 0 , and no differences were further detected.

The littorinids Nodilittorina lineolata and Littoraria flava occurred in very low densities, without any trend
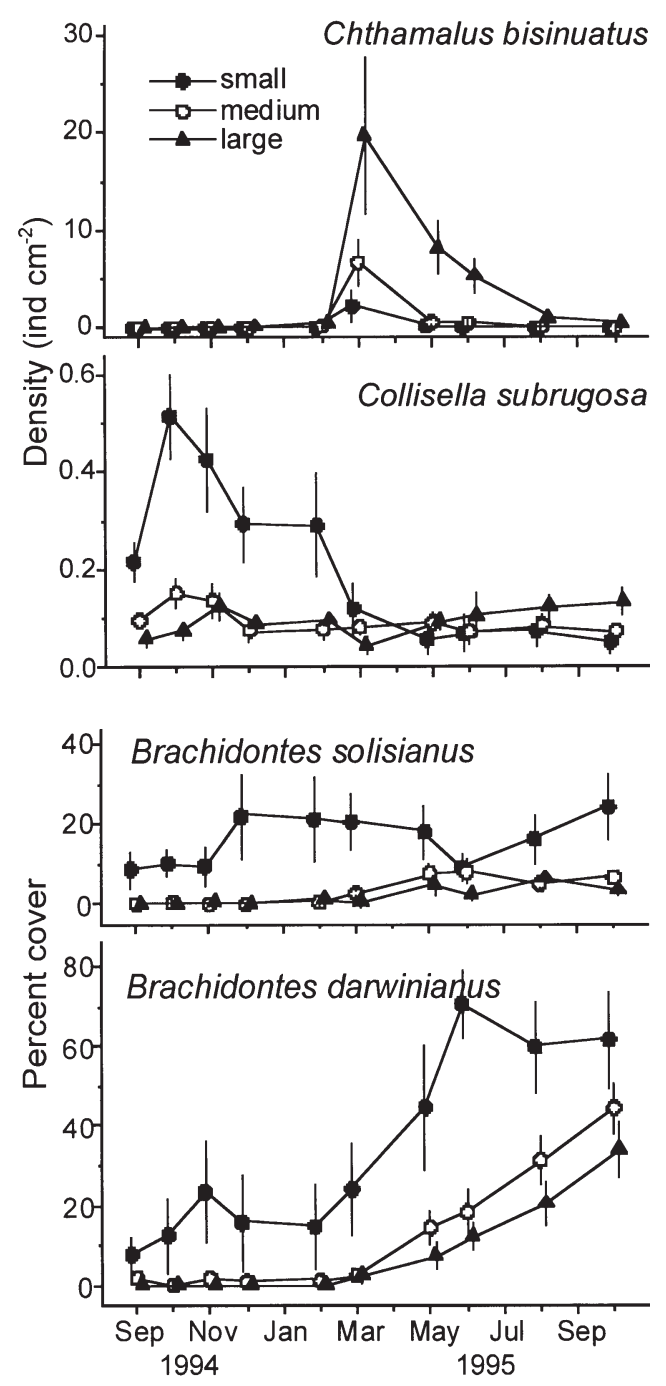

Fig. 1. Mean abundances $( \pm \mathrm{SE})$ of colonizing species in small $\left(25 \mathrm{~cm}^{-2}\right)$, intermediate $\left(100 \mathrm{~cm}^{-2}\right)$ and large clearings $\left(400 \mathrm{~cm}^{-2}\right)$ opened at Praia da Barra in the experimental gaps. Higher densities were recorded for Collisella subrugosa during the first 6 mo in the small gaps (Table 2), where the perimeter:area ratio was largest (Fig. 1); after this period, no differences were found.

The invasion of both Brachidontes species from the edges was always greater in the small gaps (Fig. 1, Table 2). In these quadrats, migration was relatively constant from the beginning of the experiment, while in larger gaps the mussels responded only after 6 mo. However, these results could be an artifact resulting from the smaller gap size, as fewer individuals would be necessary to achieve a given value of \% cover. Thus, we compared the closure rate among treatments for both species combined, using the square root of the remaining area (Fig. 2). Although 2 inflexion points can be noticed, a linear regression model was enough to explain almost $80 \%$ of the variance for the larger quadrats and $97 \%$ for the small ones. This relationship was similar among treatments, with lines differing only in height (ANCOVA, $\mathrm{r} \leq 0.99$, test for parallelism: $F_{2,27}=1.3, \mathrm{p}>0.25$; test for heights: $F_{2,27}=598.7$, $\mathrm{p}<0.001$; linear trend: $\left.F_{1,27}=140.6, \mathrm{p}<0.001\right)$. The mean closure rate was $0.26 \mathrm{~cm} \mathrm{mo}^{-1}$ for all treatments.

Although the mean response of both Brachidontes species was similar (Table 2), there were important differences in gap occupation between them. B. solisianus had a slower response when compared with $B$. darwinianus, which occupied up to 3 times more space than B. solisianus by the end of the study (Fig. 1). The mean closure rate in $100 \mathrm{~cm}^{2}$ quadrats was $0.27 \mathrm{~cm}$ $\mathrm{mo}^{-1}$ for B. solisianus, but was much higher for B. darwinianus, $1.05 \mathrm{~cm} \mathrm{mo}^{-1}$.

Recruitment differences within large gaps depended on the species (Fig. 3). Chthamalus bisinuatus had similar densities in both areas, although a trend for

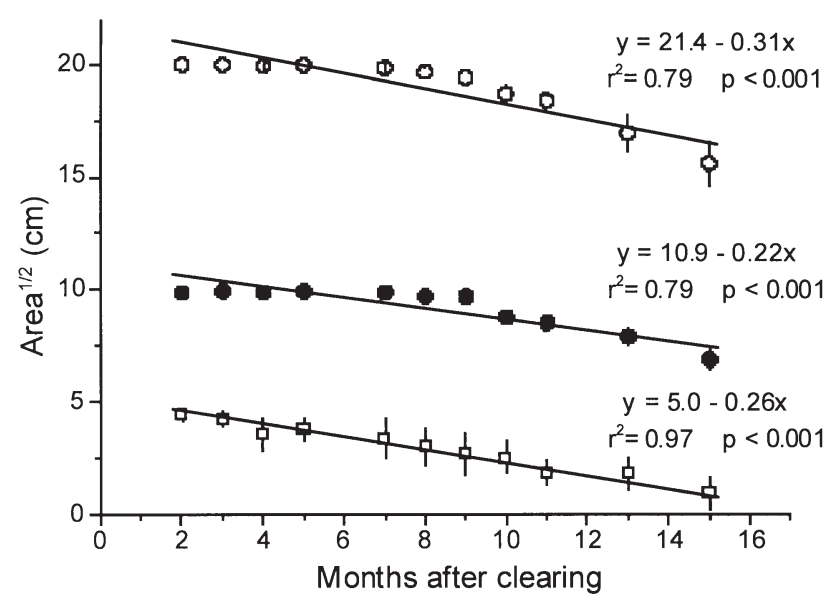

Fig. 2. Closure rates of large (O), intermediate (0) and small quadrats $(\square)$ cleared at Praia da Barra, along the studied period. The linear regression equations are also shown 
Table 2. Repeated-measures ANOVA comparing the succession patterns in distinct-sized gaps opened at Barra. WL: Wilks' lambda, MS: mean square, ${ }^{*} \mathrm{p}<0.05,{ }^{* *} \mathrm{p}<0.01,{ }^{* * *} \mathrm{p}<0.001$, ns: not significant

\begin{tabular}{|c|c|c|c|c|c|c|c|}
\hline \multirow[t]{2}{*}{ Source of variation } & \multirow[t]{2}{*}{ df } & \multicolumn{2}{|c|}{ Collisella subrugosa } & \multicolumn{2}{|c|}{ Brachidontes solisianus } & \multicolumn{2}{|c|}{ B. darwinianus } \\
\hline & & MS & $F$ & MS & $F$ & MS & $F$ \\
\hline \multicolumn{8}{|l|}{ Between subjects } \\
\hline Blocks & 5 & 0.06 & & 0.17 & & 0.92 & \\
\hline Treatment & 2 & 0.16 & $5.20^{*}$ & 1.21 & $13.37^{* *}$ & 2.91 & $10.84^{* *}$ \\
\hline Error & 10 & 0.03 & & 0.09 & & 0.27 & \\
\hline \multicolumn{8}{|l|}{ Within subjects } \\
\hline Time & 9 & 0.06 & $12.71^{* * *}$ & 0.10 & $4.73^{* *}$ & 1.21 & $49.61^{* *}$ \\
\hline Time $\times$ Treatment & 18 & 0.04 & $8.09^{* * *}$ & 0.04 & $1.97^{\mathrm{ns}}$ & 0.04 & $1.56^{\mathrm{ns}}$ \\
\hline Time $\times$ Blocks & 45 & 0.01 & & 0.03 & & 0.05 & \\
\hline Error (Time) & 90 & 0.01 & & 0.03 & & 0.02 & \\
\hline Multivariate ANOVA & & $\underline{\text { WL }}$ & $\underline{F}$ & $\underline{\mathrm{WL}}$ & $\underline{F}$ & $\underline{\text { WL }}$ & $\underline{F}$ \\
\hline Time & & 0.003 & $74.06^{*}$ & 0.043 & $4.89^{\mathrm{ns}}$ & 0.002 & $102.90^{*}$ \\
\hline Time $\times$ Treatment & & 0.0001 & $21.43^{* *}$ & 0.026 & $1.14^{\mathrm{ns}}$ & 0.00009 & $1.89^{\mathrm{ns}}$ \\
\hline Time $\times$ Blocks & & 0.00002 & & 0.0006 & & 0.001 & \\
\hline
\end{tabular}

higher densities in the center was noted (RM-ANOVA, Treatment: $F_{1,5}=8.22, \mathrm{p}=0.066$, Time $\times$ Treatment: $\left.F_{9,45}=2.18, \mathrm{p}>0.05\right)$. More Brachidontes recruits $(<0.5 \mathrm{~cm})$ were recorded in the gap center at the end of the study (RM-ANOVA, Treatment: $F_{1,5}=1.99$, $\mathrm{p}>0.05$, Time $\times$ Treatment: $\left.F_{9,45}=5.68, \mathrm{p}<0.05\right)$. The influence of the edge on Collisella was evident, with higher densities clustering along gap borders. Densities became similar as the edges were dislodged towards the central area during the succession (RMANOVA, Treatment: $F_{1,5}=22.05, \mathrm{p}<0.01$, Time $\times$ Treatment: $F_{9,45}=6.98, \mathrm{p}<0.01$ ).

\section{Gap area effects}

There were no clear trends on succession patterns among gaps with different shapes but with similar perimeter:area ratios at Praia do Lázaro. Chthamalus bisinuatus initially colonized the gaps in very low numbers (Fig. 4), but all individuals died afterwards, including those in their natural belt. Colonization densities during the abundance peaks were similar among treatments (1-way ANOVA, December 1994: $F_{3,15}=0.70$, p > 0.56; November 1995: $\left.F_{3,15}=1.61, p>0.23\right)$. Densities of the herbivore Collisella subrugosa presented a seasonal pattern in gaps with distinct areas, with no clear pattern of treatment differences (Table 3). Adults readily colonized the gaps (Fig. 4), but decreased in abundance as the experiment went on.

There was no pattern on bivalve lateral migration among different treatments (Fig. 4) and a great variation around a similar trend was recorded. The Time $x$ Treatment interaction was significant for Brachidontes solisianus in both univariate and multivariate analyses, but was significant only in multivariate analysis for $B$.
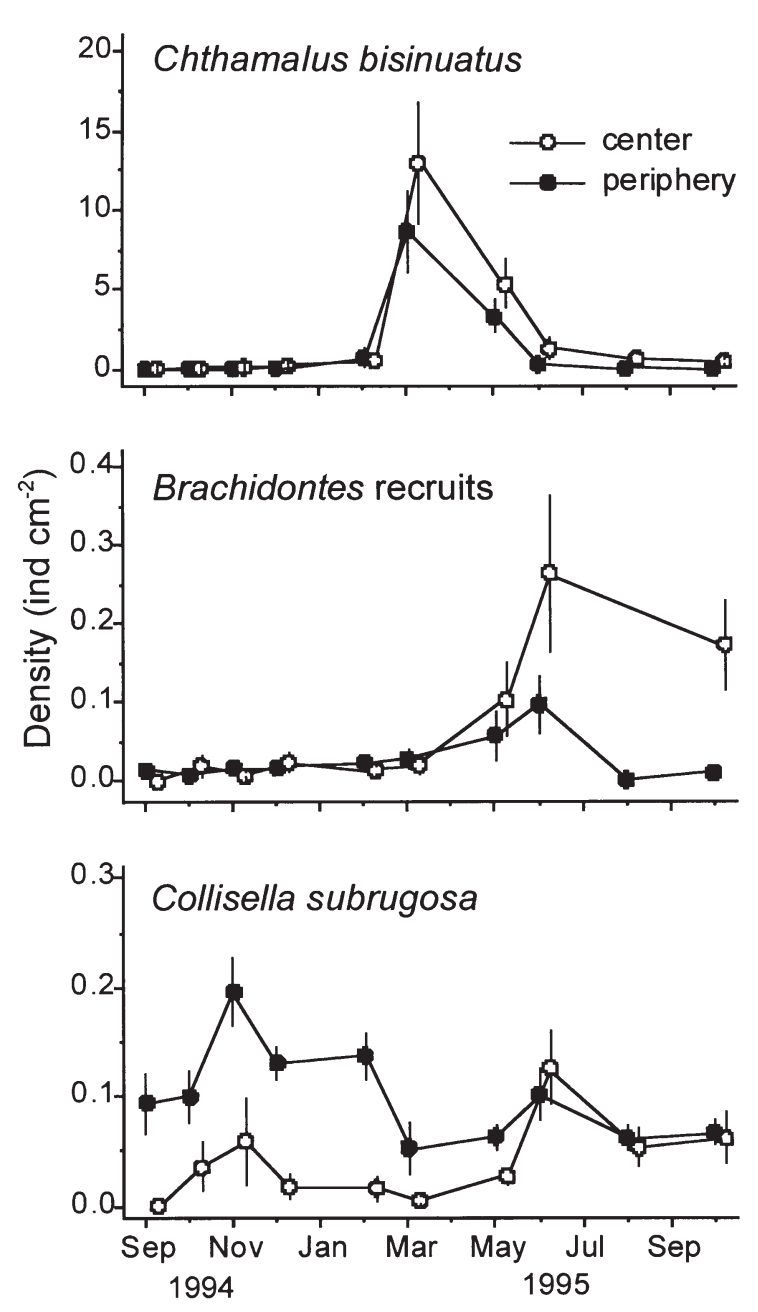

Fig. 3. Recruitment of Chthamalus bisinuatus, Brachidontes recruits and Collisella subrugosa in the center and periphery of $400 \mathrm{~cm}^{2}$ experimental clearings at Praia da Barra. Values are mean densities $( \pm \mathrm{SE})$ 
Table 3. Repeated-measures ANOVA comparing succession patterns in distinct shaped gaps but similar perimeter:area ratios opened at Lázaro. Abbreviations as in Table 2

\begin{tabular}{|c|c|c|c|c|c|c|c|}
\hline \multirow{2}{*}{ Source of variation } & \multirow[t]{2}{*}{$\mathrm{df}$} & \multicolumn{2}{|c|}{ Collisella subrugosa } & \multicolumn{2}{|c|}{ Brachidontes solisianus } & \multicolumn{2}{|c|}{ B. darwinianus } \\
\hline & & MS & $F$ & MS & $F$ & MS & $F$ \\
\hline \multicolumn{8}{|l|}{ Between subjects } \\
\hline Blocks & 5 & 0.006 & & 0.098 & & 0.78 & \\
\hline Treatment & 3 & 0.004 & $1.21^{\mathrm{ns}}$ & 0.157 & $7.11^{* *}$ & 0.27 & $2.17^{\mathrm{ns}}$ \\
\hline Error & 15 & 0.003 & & 0.022 & & 0.12 & \\
\hline \multicolumn{8}{|l|}{ Within subjects } \\
\hline Time & 8 & 0.017 & $28.62^{* * *}$ & 0.236 & $44.30^{* * *}$ & 0.72 & $40.17^{* * *}$ \\
\hline Time $\times$ Treatment & 24 & 0.001 & $0.91^{\mathrm{ns}}$ & 0.019 & $3.54^{* * *}$ & 0.03 & $1.86^{\mathrm{ns}}$ \\
\hline Time $\times$ Blocks & 40 & 0.002 & & 0.009 & & 0.04 & \\
\hline Error (Time) & 120 & 0.001 & & 0.005 & & 0.02 & \\
\hline Multivariate ANOVA & & $\underline{\mathrm{WL}}$ & $\underline{F}$ & $\underline{\mathrm{WL}}$ & $\underline{F}$ & $\underline{\mathrm{WL}}$ & $\underline{F}$ \\
\hline Time & & 0.05 & $18.90^{* * *}$ & 0.012 & $82.45^{* * *}$ & 0.039 & $24.30^{* * *}$ \\
\hline Time $\times$ Treatment & & 0.20 & $0.74^{\mathrm{ns}}$ & 0.004 & $5.93^{* * *}$ & 0.028 & $2.40^{*}$ \\
\hline Time $\times$ Blocks & & 0.01 & & 0.016 & & 0.007 & \\
\hline
\end{tabular}
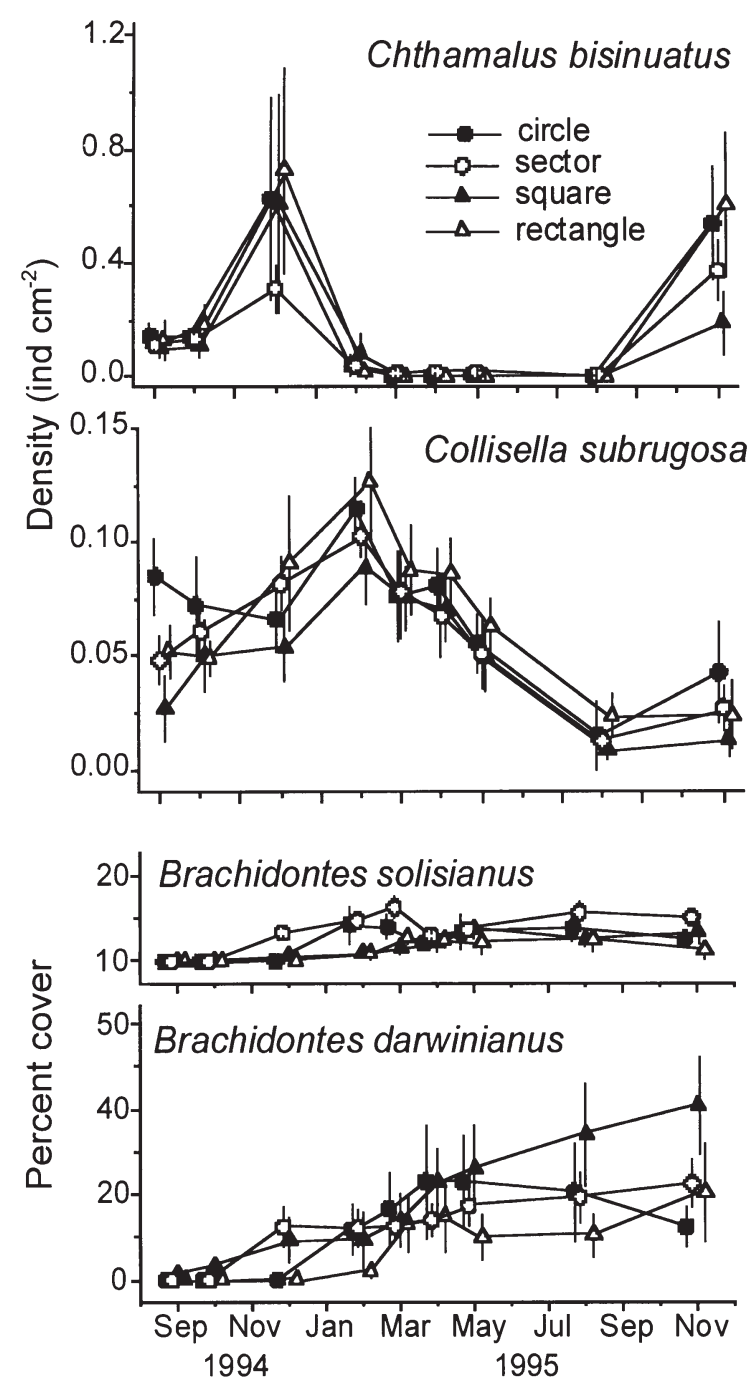

Fig. 4. Mean abundances $( \pm \mathrm{SE})$ of colonizing species in different-shaped clearings opened at Praia do Lázaro darwinianus (Table 3). Similar to succession patterns in Barra, \% cover by B. darwinianus was higher than for B. solisianus.

\section{DISCUSSION}

This study demonstrated that the main edge effects on the succession dynamics of patches opened within Brachidontes mussel beds result from the relationship between the perimeter and area of these gaps (e.g. Paine \& Levin 1981). When the perimeter:area ratio was constant for different-sized patches, there was a great variation between succession velocity and dynamics among these patches; however, there was also a similar trend. When patch size was manipulated (area and perimeter:area ratio), significant differences of densities of colonizing species were found.

The abundance of the herbivore Collisella subrugosa depends on periphery length relative to total patch area. Collisella subrugosa remains in patch edges, a behavior that was interpreted for other Collisella species as a defense against visually oriented predators (Mercurio et al. 1985), or as a refuge against desiccation and wave impact (Sousa 1984a, Farrell 1989). Herbivore densities in rocky shore patches are limited by existing refuges, measured by the amount of borders with the surrounding community (Farrell 1989). Thus, more edge areas to total area should result in greater herbivore densities (Sousa 1984a,b). Further, as limpets colonize natural gaps in mussel beds, they gain access to a larger supply of microalgae in relation to mussel shells, although food availability could eventually become limiting (Branch 1981). Both factors (shelter and food) can possibly interact to determine the maximum number of individuals that can stay in the gaps, 
influencing herbivore distribution. In fact, Iwasaki (1999) found during 1 mo of observation that 10 to $30 \%$ of marked Patella flexuosa within mussel gaps moved to other gaps that had a lower limpet density.

Colonization of the barnacle Chthamalus bisinuatus occurred in different times for both shores. Studies at other shores of the region suggest that $C$. bisinuatus recruits over the whole year, but our data suggest that some irregular peaks may occur, at least in the amongshore scale (Eston et al. 1986, Tanaka \& Duarte 1998). Barnacle colonization was dependent on patch size, with greater densities in the $400 \mathrm{~cm}^{2}$ patches at Barra. However, densities were similar in patches that differed in area but had the same perimeter:area ratio at Lázaro. These patterns could be due to the effect of Collisella subrugosa, dislodging the barnacles from the substrate (e.g. Dayton 1971, Safriel et al. 1994). A similar pattern was observed between the edge and center of large patches. Although barnacle densities did not differ within a patch, a trend toward larger densities in the center was noted $(p=0.066)$, while densities of $C$. subrugosa were higher at the edges. Thus, central areas of the patches could accumulate more barnacles, causing a reduction in herbivore densities as they can use the peripheric areas to forage. In smaller patches, C. subrugosa possibly uses the whole patch, reducing barnacle densities. Further experimentation will be needed to evaluate the interaction between these 2 species and their influence on SE Brazilian rocky shore communities.

The influence of the undisturbed community on gap closure results from lateral migration of the mussel bed species. There was a consistent pattern of space occupancy on patches with distinct edge relationships: the migration rate was similar among the 3 gap sizes studied (Fig. 1), resulting in faster closure of the smaller gaps. When the same perimeter:area ratio was used in Lázaro, apparently random variations toward a general trend characterized patch closure. The opening of small gaps in Brachidontes mussel beds, which are rapidly recolonized by lateral migration, could help to stabilize this assemblage. When mussel density is very high, the byssus matrix can lose contact with the substrate, resulting in a small elevation of the mussel bed —a hummock (e.g. Seed \& Suchanek 1992). These hummocks are easily dislodged by wave action, forming small gaps that can be readily recolonized. Thus, a greater bed stability can result from higher turnover rates and lower densities, guaranteeing substrate dominance by the mussels. Larger gaps, on the other hand, demand more time to close by lateral migration, and recruitment can play a major role on succession (e.g. Paine \& Levin 1981, Sousa 1984b). Thus, greater species diversity could be detected only when there are patches large enough to support colonization and dom- inance of the substrate by organisms from the water column, so that a mosaic of patches in different succession stages can be maintained (Tokeshi \& Romero 1995).

Mean closure rate for mixed Brachidontes beds $\left(0.26 \mathrm{~cm} \mathrm{mo}^{-1}\right)$ was lower than those observed for other mussel species: $1.6 \mathrm{~cm} \mathrm{mo}^{-1}$ for Mytilus californianus (Paine \& Levin 1981) and $1.2 \mathrm{~cm} \mathrm{mo}^{-1}$ for Semimytilus algosus (Tokeshi \& Romero 1995). However, when individual species are considered, $B$. darwinianus has a much faster response than $B$. solisianus. The dynamics of disturbance and subsequent gap formation in Brachidontes mussel beds could influence the distribution of both B. solisianus and B. darwinianus. Nalesso et al. (1990) showed that B. solisianus occurred in higher regions in the intertidal at sites with higher salinity, while $B$. darwinianus occurred in lower regions and at sites more subject to lower salinities. Also, $B$. darwinianus has a higher growth rate than $B$. solisianus and may expand its distribution in the intertidal zone, confining $B$. solisianus to higher regions (Nalesso et al. 1990). The results of our study indicate that $B$. darwinianus can expand the area occupied by rapidly migrating to bare rock patches opened in the mussel bed. Disturbance of the mussel bed is rather continuous, although in the winter larger gaps can be created in exposed shores (Nalesso et al. 1990). Thus, B. darwinianus can present a larger turnover rate in the areas studied, while $B$. solisianus is continuously taken from the mussel bed, eventually becoming locally extinct (Petersen et al. 1986). Dominance of the rocky shore by $B$. solisianus could only occur again after a massive recruitment event (Petersen et al. 1986).

The influence of patch size on succession dynamics of intertidal communities may depend on the composition of the surrounding community. In mussel beds, small gaps are readily closed by lateral migration; while in large gaps, recruitment from the water column can contribute more to succession. In algal-dominated communities, the lateral invasion rate is determined by vegetative growth and propagule colonization from the edges (Sousa 1985). The surrounding assemblage can negatively influence algal colonization on small gaps due to the effects of whiplashing and shading, recovery of large gaps can be delayed due to lower colonization or higher mortality; thus, succession can be faster in intermediate-sized gaps (Kim \& DeWreede 1996). At sites dominated by barnacles, gap colonization should occur mainly by species recruitment from the water column; thus, the effect of herbivores must be greater, negatively influencing propagule colonization (Farrell 1989, 1991). On the other hand, barnacles can facilitate mussel recruitment in small gaps, as mussels settle on walls of barnacles present in gap borders, although dominating the space 
in larger gaps (Navarrette \& Castilla 1990). Facilitation of recruitment by conspecifics may also depend on gap size, with larger effects on gaps with a larger P:A ratio, potentially influencing the population dynamics of these organisms (e.g. Minchinton 1997, Jeffery 2000). Thus, succession dynamics in bare rock patches opened in intertidal communities should differ among assemblages with distinct compositions, and the relative influence of consumer, recruiting and neighboring species on succession patterns should only be generalized in similar systems.

Acknowledgements. We thank A. L. T. Souza for invaluable discussions and help in the field, A. Petenate for statistical advice, S. C. Buys for the identification of algae, R. T. Davis for checking the English, and all our friends who helped with the field work, especially T. E. M. Duque-Estrada. M.O.T. received financial support from FAPESP (procs 95/2260-0 and 96/3733-1) and FMB (proc B68).

\section{LITERATURE CITED}

Branch GM (1981) The biology of limpets: physical factors, energy flow and ecological interactions. Oceanogr Mar Biol Annu Rev 19:235-380

Connell JH, Keough MJ (1985) Disturbance and patch dynamics of subtidal marine animals on hard substrata. In: Pickett STA, White OS (eds) The ecology of natural disturbance and patch dynamics. Academic Press, Orlando, FL, p 125-151

Connell JH, Slatyer RO (1977) Mechanisms of succession in natural communities and their role in community stability and organization. Am Nat 111:1119-1144

Dayton PK (1971) Competition, disturbance and community organization: the provision and subsequent utilization of space in a rocky intertidal community. Ecol Monogr 41: 351-389

Dean TA, Hurd LE (1980) Development in an estuarine fouling community: the influence of early colonists on later arrivals. Oecologia 46:295-301

Eston VR, Bussab WO (1990) An experimental analysis of ecological dominance in a rocky subtidal macroalgal community. J Exp Mar Biol Ecol 136:170-195

Eston VR, Galves A, Jacobi CM, Langevin R, Tanaka NI (1986) Chthamalus bisinuatus (Cirripedia) and Brachidontes solisianus (Bivalvia) spatial interactions: a stochastic model. Ecol Model 34:99-113

Farrell TM (1989) Succession in a rocky intertidal community: the importance of disturbance size and position within a disturbed patch. J Exp Mar Biol Ecol 128:57-73

Farrell TM (1991) Models and mechanisms of succession: an example from a rocky intertidal community. Ecol Monogr 61:95-113

Hurlbert SJ (1984) Pseudoreplication and the design of ecological field experiments. Ecol Monogr 54:187-211

Iwasaki K (1999) Short- and long-term movements of the patellid limpet Patella flexuosa within gaps in intertidal mussel beds. J Molluscan Stud 65:295-301

Jeffery CJ (2000) Settlement in different-sized patches by the gregarious intertidal barnacle Chamaesipho tasmanica Foster and Anderson in New South Wales. J Exp Mar Biol Ecol 252:15-26
Johnscher-Fornasaro G, Lopes CF, de Milanelli JC (1990) Similaridade faunística entre comunidades da zona entremarés de costões rochosos do litoral norte do Estado de São Paulo. II Simpósio de Ecossistemas da Costa Sul e Sudeste Brasileira: Estrutura, Função e Manejo, Vol 3, ACIESP, São Paulo, p 75-88 (in Portugese)

Keough MJ (1984) Effects of patch size on the abundance of sessile marine invertebrates. Ecology 65:423-437

Kim JH, DeWreede RE (1996) Effects of size and season of disturbance on algal patch recovery in a rocky intertidal community. Mar Ecol Prog Ser 133:217-228

Klappenbach MA (1965) Lista preliminar de los Mytilidae brasileños con claves para su determinación y notas sobre su distribucion. An Acad Bras Cienc (Suppl) 37:327-352

Levin AS, Paine RT (1974) Disturbance, patch formation, and community structure. Proc Natl Acad Sci USA 71: $2744-2747$

Mercurio KS, Palmer AR, Lowell RB (1985) Predator-mediated microhabitat partitioning by two species of visually cryptic, intertidal limpets. Ecology 66:1417-1425

Minchinton TE (1997) Life on the edge: conspecific attraction and recruitment of populations to disturbed habitats. Oecologia 111:45-52

Nalesso RC, Duarte LFL, Mendes EG (1990) Influência da salinidade e exposição ao ar na dsitribuição dos mexilhões Brachidontes darwinianus e $B$. solisianus em estuários do litoral do Estado de São Paulo. Anais do II Simpósio de Ecossistemas da Costa Sul e Sudeste Brasileira, Vol 3, ACIESP, São Paulo, p 111-122 (in Portugese)

Navarrette AS, Castilla JC (1990) Barnacle walls as mediators of intertidal mussel recruitment: effects of patch size on the utilization of space. Mar Ecol Prog Ser 68:113-119

Paine RT, Levin SA (1981) Intertidal landscapes: disturbance and the dynamics of pattern. Ecol Monogr 51:145-178

Petersen JA, Sutherland JP, Ortega S (1986) Patch dynamics of mussel beds near São Sebastião (São Paulo), Brazil. Mar Biol 92:389-393

Safriel UN, Erez N, Keasar T (1994) How do limpets maintain barnacle-free submerged artificial surfaces? Bull Mar Sci $54: 17-23$

Seed R, Suchanek TH (1992) Population and community ecology of Mytilus. In: Gosling E (ed) The mussel Mytilus: ecology, physiology, genetics and culture. Elsevier Science Publishers, Amsterdam, p 87-163

Sousa WP (1984a) The role of disturbance in natural communities. Annu Rev Ecol Syst 15:353-391

Sousa WP (1984b) Intertidal mosaics: patch size, propagule availability, and spatially variable patterns of succession. Ecology 65:1918-1935

Sousa WP (1985) Disturbance and patch dynamics on rocky intertidal shores. In: Pickett STA, White OS (eds) The ecology of natural disturbance and patch dynamics. Academic Press, New York, p 101-124

Tanaka MO, Duarte LFL (1998) Recruitment variation of the barnacle Chthamalus bisinuatus Pilsbry 1916 in an exposed rocky shore in southeast Brazil. Bull Mar Sci 62: 285-292

Tokeshi M, Romero L (1995) Filling a gap: dynamics of space occupancy on a mussel-dominated subtropical rocky shore. Mar Ecol Prog Ser 119:167-176

Underwood AJ, Denley EJ, Moran MJ (1983) Experimental analysis of the structure and dynamics of mid-shore rocky intertidal communities in New South Wales. Oecologia 56: 202-219

Winer BJ (1971) Statistical principles and experimental design, 2nd edn. McGraw-Hill, New York 